\title{
PENGARUH PELATIHAN (BHD) TERHADAP PENGETAHUAN DAN KETERAMPILAN MAHASISWA KESEHATAN MASYARAKAT
}

\author{
Vina Nirmalasari, Wiwin Winarti \\ Fakultas Ilmu Kesehatan \\ Universitas Pembangunan Nasional Veteran Jakarta
}

\begin{abstract}
ABSTRAK
Out-of-Hospital Cardiac Arrest (OHCA) merupakan keadaan hilangnya fungsi jantung secara tibatiba yang terjadi di luar rumah sakit dan membutuhkan pertolongan cepat. Bantuan Hidup Dasar (BHD) merupakan pertolongan pertama kepada korban OHCA yang dapat meningkatkan angka keberlangsungan hidup pasien henti jantung. Setiap lapisan masyarakat khususnya mahasiswa kesehatan harus memiliki pengetahuan dan keterampilan BHD. Pelatihan dapat meningkatkan pengetahuan dan keterampilan mahasiswa jurusan kesehatan. Tujuan dari penelitian ini adalah untuk mengetahui pengaruh pelatihan bantuan hidup dasar terhadap pengetahuan dan keterampilan pada Himpunan Mahasiswa Kesehatan Masyarakat (HMKM) di UPN "Veteran" Jakarta. Penelitian ini menggunakan desain Quasi Experiment Design (Eksperimental Semu) dengan Pre-Post Without Control Group. Teknik Consecutive sampling digunakan untuk merekrut 23 mahasiswa sebagai responden penelitian. Hasil analisis menggunakan Paired t-test menunjukkan terdapat pengaruh yang signifikan antara pelatihan BHD dengan pengetahuan $(p=0,000)$ dan keterampilan $(p=0,000)$. Hal tersebut menunjukkan terdapat pengaruh yang signifikan antara pelatihan BHD dengan pengetahuan dan keterampilan HMKM UPN “Veteran” Jakarta.
\end{abstract}

Kata Kunci : BHD, Keterampilan, Pelatihan, Pengetahuan

\begin{abstract}
Out of Hospital Cardiac Arrest (OHCA) is a state of a sudden loss of heart function that occurs outside the hospital and requires rapid relief. Basic Life Support (BLS) is the first aid that can increase the survival rate of patients with cardiac arrest of OHCA victims. Every level of society, especially healthcare students, is mandatory to have BLS knowledge and skills. Training can improve healthcare students' knowledge and skills. The purpose of this study was to determine the effect of basic life support training on the knowledge and skills of the members of the Public Health Student Association at UPN "Veteran" Jakarta. This study used a Quasi Experiment with Pre-Post Without Control Group design. The consecutive sampling method was used to recruit 23 students as respondents. The results of a Paired $t$-test showed that there was a significant effect of BLS training on the knowledge $(p=0,000)$ and skills $(p=0,000)$. This study showed that there is a significant effect of BLS training on the knowledge and skills of the members of the Public Health Student Association at UPN "Veteran" Jakarta.
\end{abstract}

Keywords: BLS; Knowledge; Skill; Training

Alamat korespondensi: Kampus Fikes UPN Veteran Jakarta, Jalan Limo Raya Depok

Email : Wiwin.winarti@upnvj.ac.id 


\section{PENDAHULUAN}

Henti jantung atau cardiac arrest merupakan keadaan hilangnya fungsi jantung secara tiba-tiba yang sebagian besar terjadi karena kerusakan pada sistem kelistrikan jantung. Saat jantung berhenti berdetak, tidak ada pasokan darah yang dialirkan keseluruh tubuh termasuk organ-organ vital seperti otak (American Heart Association, 2017). Keadaan ini dapat menyebabkan kecacatan serta kerusakan otak yang permanen (Graham dkk, 2015). Henti jantung selain menyebabkan kerusakan organ juga memiliki angka kejadian yang tinggi baik di dalam rumah sakit maupun di luar rumah sakit.

Out-of-Hospital Cardiac Arrest (OHCA) atau yang lebih dikenal dengan henti jantung yang terjadi di luar rumah sakit memiliki angka kejadian yang tinggi. Menurut American Heart Association prevalensi OHCA di Amerika Serikat pada tahun 2015 sebanyak 326.000 kasus (AHA, 2015). Pada penelitian lain di Inggris terdapat 28.000 kasus OHCA di tahun 2014 (Hawkes dkk, 2017). Angka kejadian OHCA dibeberapa negara di Asia pada tahun 2009-2012 tercatat 66.000 kasus (Ong dkk, 2015). Tingginya angka kejadian OHCA dapat menyebabkan angka kematian yang tinggi pula. Pencegahan kematian pada korban OHCA dapat dilakukan dengan memberikan pertolongan segera berupa bantuan hidup dasar oleh orang disekitar korban.

Menurut Yayasan Ambulans Gawat Darurat 118 bantuan hidup dasar (BHD) atau yang juga dikenal dengan Basic Life Support (BLS) merupakan pertolongan segera yang diberikan pada penderita henti jantung dan henti napas, meliputi aktivasi sistem tanggap darurat, melakukan Resusitasi Jantung Paru (RJP), dan melakukan defibrilasi menggunakan Automated External Defibrillator (AED) (YAGD 118, 2018). Resusitasi Jantung Paru (RJP) yang terdapat dalam BHD merupakan tindakan yang dimaksudkan untuk menyirkulasikan darah ke organ vital guna mencegah terhentinya sirkulasi dan respirasi yang dapat menyebabkan kematian (Ganthikumar, 2017). Menurut YAGD 118 semakin cepat memberikan bantuan hidup dasar maka kemungkinan selamat bagi korban akan meningkat.

Kelangsungan hidup korban OHCA jauh lebih mungkin ketika terdapat penolong disekitar korban yang memberikan bantun hidup dasar, mulai dari menghubungi rumah sakit atau ambulans hingga segera memberikan RJP. Bantuan hidup dasar dapat meningkatkan keberlangsungan hidup pasien OHCA hingga hampir 45\% (AHA, 2018). Penelitian lain di Inggris menunjukkan keberlangsungan hidup pasien OHCA mencapai 25,8\% setelah mendapatkan bantuan hidup dasar (Hawkes dkk, 2017). Disimpulkan bahwa keberlangsungan hidup orang henti jantung akan meningkat dengan diberikannya bantuan hidup dasar.

Penelitian yang dilakukan di beberapa negara menunjukkan masih rendahnya pemberian bantuan hidup dasar pada korban henti jantung. Pemberian BHD pada korban OHCA di Amerika pada tahun 2015 sebanyak 45,9\% (AHA, 2015). Penelitian lain menyatakan pemberian BHD pada korban OHCA di Sweden mencapai 51,1 \% (Hasselqvist-Ax dkk, 2015). Penelitian juga dilakukan di Jordan pada tahun 2014 yang menyatakan hanya 22\% orang memberikan pertolongan BHD pada korban OHCA, rendahnya pemberian pertolongan BHD ini didasari kurangnya pengetahuan dan keterampilan dari penolong (Raffee dkk, 2017)

Seluruh lapisan masyarakat baik anak-anak, remaja, dewasa, maupun lansia seharusnya memiliki pengetahuan dan keterampilan BHD. Sebagai bagian dari masyarakat, mahasiswa kesehatan merupakan agent of change dalam meningkatkan kualitas kesehatan masyarakat. Sangat penting bagi mahasiswa kesehatan memiliki pengetahuan dan keterampilan BHD yang mana merupakan indikator keberhasilan dalam menyelamatkan korban henti jantung (Yunus dkk, 2015).

Pengetahuan mahasiswa kesehatan terkait bantuan hidup dasar diluar maupun dalam negeri masih menunjukkan hasil yang rendah. Penelitian yang dilakukan pada mahasiswa fakultas kesehatan di Saudi Arabia pada tahun 2017 menyatakan dari 1.349 responden, sebanyak 1.186 $(87,9 \%)$ mahasiswa memiliki pengetahuan yang sangat rendah, $120(8.9 \%)$ mahasiswa berpengetahuan rendah, 41 (3.0\%) mahasiswa berpengetahuan cukup dan hanya $2(0.1 \%)$ mahasiswa yang memiliki pengetahuan baik terkait bantuan hidup dasar (Al-Mohaissen, 2017). Hasil penelitian ini sejalan dengan penelitian yang dilakukan oleh Suranadi (2017) yang dilakukan 
pada mahasiswa fakultas kesehatan di Bali menunjukkan dari 170 responden, sebanyak 163 (95,9\%) mahasiswa memiliki pengetahuan kurang, 7 (4,1\%) mahasiswa memiliki pengetahuan sedang, dan penelitian ini menunjukkan tidak ada satupun mahasiswa yang memiliki pengetahuan baik. Kedua penelitian ini menunjukkan masih rendahnya pengetahuan masyarakat khususnya mahasiswa kesehatan terkait pemberian bantuan hidup dasar. Rendahnya pengetahuan ini dapat ditingkatkan dengan mengikuti pelatihan BHD.

Pelatihan bantuan hidup dasar bertujuan untuk meningkatkan pengetahuan dan keterampilan dalam pemberian bantuan yang tepat. Sebuah penelitian yang dilakukan oleh Sansare dan Jacob pada tahun (2018) kepada 60 pegawai administrasi mengenai pengaruh pelatihan bantuan hidup dasar terhadap pengetahuan dan keterampilan. Penelitian tersebut menggunakan alat ukur kuesioner dan lembar observasi. Hasil pre-test menunjukkan 39 (60\%) responden memiliki pengetahuan yang rendah dan $60(100 \%)$ responden memiliki keterampilan yang rendah. Setelah pelatihan didapatkan hasil post-test 42 (70\%) responden berpengetahuan cukup dan 56 (93,3\%) responden memiliki keterampilan yang baik. Penelitian tersebut menunjukkan bahwa terjadi peningkatan pengetahuan dan keterampilan setelah diberikan pelatihan $(\mathrm{p}<0.05)($ Sansare \& Jacob, 2018).

Studi pendahuluan telah dilakukan pada 10 anggota himpunan mahasiswa kesehatan masyarakat di UPN "Veteran" Jakarta. Hasil studi pendahuluan didapatkan sebanyak 7 (70\%) mahasiswa belum pernah mendapatkan informasi atau pengalaman terkait BHD dan sebanyak 3 $(30 \%)$ mahasiswa pernah mendapatkan informasi atau pengalaman terkait BHD. Pengalaman terkait BHD didapatkan dari mengikuti kegiatan Palang Merah Remaja saat duduk di bangku sekolah. Seluruh mahasiswa dapat menjawab pengertian dari BHD, namun sebanyak $8(80 \%)$ mahasiswa salah menjawab terkait tindakan yang harus dilakukan pertama kali saat melihat pasien tidak sadarkan diri di tengah jalan, 8 orang $(80 \%)$ salah menjawab kecepatan atau frekuensi kompresi dada, dan sebanyak 5 orang $(50 \%)$ salah dalam menjawab pertanyaan terkait lokasi tangan saat melakukan kompresi dada yang tepat.

Pelatihan BHD menjadi kebutuhan yang mendesak dalam peningkatan pengetahuan dan keterampilan individu untuk cepat tanggap dalam menangani kasus henti jantung. Pelatihan BHD dapat berdampak besar dalam meningkatkan kesadaran masyarakat terkait RJP yang sangat penting untuk meningkatkan kelangsungan hidup korban henti jantung. Berdasarkan hal tersebut peneliti ingin mengetahui "Pengaruh Pelatihan Bantuan Hidup Dasar (BHD) Terhadap Pengetahuan dan Keterampilan Pada Himpunan Mahasiswa Kesehatan Masyarakat di Universitas Pembangunan Nasional "Veteran" Jakarta".

\section{METODE PENELITIAN}

Penelitian ini menggunakan desain penelitian quasi-eksperimental pre and post-test without control group. Jumlah sampel sebanyak 23 mahasiswa dengan teknik pengambilan sampel yaitu non probability sampling, metode sampling yang digunakan adalah consecutive sampling. Sampel dari penelitian ini adalah himpunan mahasiswa kesehatan masyarakat di UPN "Veteran" Jakarta yang mengacu kepada kriteria inklusi dan eksklusi. Penelitian ini menggunakan kuesioner dan lembar observasi sebagai instrumen penelitian. Teknik pengolahan data menggunakan Paired t-test. Penelitian ini telah mendapatkan izin etik pada institusi Universitas Pembangunan Nasional “Veteran" Jakarta dengan nomor B/2017/VI/2019/KEPK

\section{HASIL DAN PEMBAHASAN}

Berdasarkan data distribusi rata-rata pada tabel 1 didapatkan hasil rata-rata usia responden Mahasiswa Himpunan Kesehatan Masyarakat di UPN "Veteran" Jakarta yaitu 19,30 dengan standard deviasi 0,765. Pada tabel tersebut terlihat usia minimal responden yaitu 18 tahun dan usia maksimal responden yaitu 21 tahun. Hasil penelitian juga menunjukkan bahwa jumlah responden dalam penelitian ini lebih banyak perempuan dibandingkan responden laki-laki dan seluruh responden yang berjumlah $(100 \%)$ belum pernah mengikuti pelatihan bantuan hidup dasar. 
Berdasarkan sumber informasi terkait bantuan hidup dasar terbanyak didapat melalui media elektronik yaitu tv dan internet sebanyak 10 responden (43,5\%). Sumber informasi terendah yaitu melalui seminar/penyuluhan yaitu 1 responden (4,3\%) dan lain-lain yaitu 1 responden $(4,3 \%)$. Tabel ini menunjukkan kecenderungan mahasiswa yang mendapatkan informasi melalui media elektronik baik tv maupun internet (tabel 2).

Tabel 1 Distribusi Rata-Rata Responden berdasarkan Usia Anggota Himpunan Mahasiswa Kesehatan Masyarakat di UPN “Veteran” Jakarta

\begin{tabular}{ccccccc}
\hline \multirow{2}{*}{ Karakteristik } & \multirow{2}{*}{ Mean } & \multirow{2}{*}{ SD } & \multirow{2}{*}{ Min-Max } & \multicolumn{2}{c}{ 95\% CI } \\
\cline { 5 - 6 } & & & & Lower & Upper \\
\hline Usia & 19,30 & 0,765 & $18-21$ & 18,97 & 19,64 \\
\hline
\end{tabular}

Tabel 2 Distribusi Frekuensi Responden berdasarkan Jenis Kelamin, Pelatihan, dan Sumber informasi BLS Mahasiswa Himpunan Kesehatan Masyarakat di UPN “Veteran” Jakarta

\begin{tabular}{ccc}
\hline Jenis Kelamin & Frekuensi & Persentase \\
\hline Laki-Laki & 7 & $30,4 \%$ \\
Perempuan & 16 & $69,6 \%$ \\
\hline Pelatihan & & $0 \%$ \\
Pernah & 0 & $100 \%$ \\
Tidak Pernah & 23 & \\
\hline Sumber Informasi & & $4,3 \%$ \\
Seminar/Penyuluhan & 1 & $8,7 \%$ \\
Majalah/koran & 2 & $8,7 \%$ \\
Buku & 2 & $43,5 \%$ \\
Media Elektronik & 10 & $30,4 \%$ \\
Ekstrakulikuler & 7 & $4,3 \%$ \\
Lain-lain & 1 &
\end{tabular}

Tabel 3 Distribusi Rata-Rata Responden berdasarkan Pengetahuan Sebelum dan Sesudah Pelatihan Mahasiswa Himpunan Kesehatan Masyarakat di UPN "Veteran" Jakarta

\begin{tabular}{|c|c|c|c|c|c|c|}
\hline & \multirow{2}{*}{ Mean } & \multirow{2}{*}{ SD } & \multirow{2}{*}{$\begin{array}{c}\text { Mean } \\
\text { difference }\end{array}$} & \multicolumn{2}{|c|}{$95 \%$ CI } & \multirow{2}{*}{$P$ value } \\
\hline & & & & Lower & Upper & \\
\hline Pengetahuan sebelum & 15,09 & 2,21 & \multirow{2}{*}{$-4,957$} & \multirow{2}{*}{$-5,97$} & \multirow{2}{*}{$-3,94$} & \multirow{2}{*}{0,000} \\
\hline Pengetahuan sesudah & 20,04 & 0,87 & & & & \\
\hline Keterampilan sebelum & 4,57 & 1,99 & \multirow{2}{*}{$-11,65$} & \multirow{2}{*}{$-12,61$} & \multirow{2}{*}{$-10,68$} & \multirow{2}{*}{0,000} \\
\hline Keterampilan sesudah & 16,22 & 1,20 & & & & \\
\hline
\end{tabular}

Penelitian menunjukkan rata-rata pengetahuan responden sebelum mendapatkan pelatihan adalah 15,09 dengan standar deviasi 2,21 dan sesudah diberikan pelatihan bantuan hidup dasar rata-rata pengetahuan responden adalah 20,04 dengan standar deviasi 0,87. Hasil analisis bivariat menggunakan uji paired simple t-test, diperoleh hasil mean difference sebesar $-4,957$ dan nilai $\mathrm{P}$ Value yaitu 0,000 ( $<<0,05)$ (tabel 3). Hasil ini dapat disimpulkan Ho ditolak sehingga terdapat pengaruh yang signifikan terhadap pengetahuan sebelum dan sesudah pemberian pelatihan bantuan hidup dasar. Uji statistik juga menunjukkan bahwa rata-rata keterampilan sebelum mendapatkan pelatihan yaitu 4,57 dengan standar deviasi 1,99 dan rata-rata keterampilan setelah diberikan 
pelatihan bantuan hidup dasar yaitu 16,22 dengan standar deviasi 1,20. Hasil analisa bivariat menggunakan uji paired sample t-test, didapatkan nilai significancy yaitu 0,000 ( $\mathrm{p}<0,05)$. Hasil uji statistik ini menunjukkan pengaruh yang signifikan terhadap keterampilan sebelum dan sesudah diberikan pelatihan bantuan hidup dasar (tabel 3).

Hasil penelitian ini sejalan dengan penelitian yang dilakukan oleh Owojuyigbe,dkk (2015) terkait pengaruh pelatihan bantuan hidup dasar terhadap pengetahuan dengan nilai $p=0,01<0,05$, hasil ini dapat disimpulkan terdapat pengaruh pelatihan terhadap pengetahuan. Berdasarkan penelitian lain yang dilakukan Ghauri, dkk (2019) tentang pengaruh pelatihan bantuan hidup dasar terhadap pengetahuan dengan nilai $\mathrm{p}=0,01<0,05$ dapat disimpulkan terdapat pengaruh pelatihan terhadap pengetahuan. Pada penelitian Prasetyo (2019) mengenai pengaruh pelatihan bantuan hidup dasar terhadap pengetahuan tim muhammadiyah disaster management didapatkan nilai $\mathrm{p}=0,0001<0,05$ dapat disimpulkan terdapat pengaruh pelatihan terhadap pengetahuan.

Pelatihan merupakan proses pendidikan jangka pendek yang menyatukan pembelajaran secara teori dan praktek, sehingga pelatihan merupakan faktor yang dapat meningkatkan pengetahuan seseorang (Larasati, 2018). Pelatihan dapat mempengaruhi pengetahuan secara signifikan karena memiliki faktor-faktor pendukung. Salah satu faktor yang menjadikan pelatihan dengan metode simulasi dapat meningkatkan pengetahuan yaitu karena peserta dibimbing langsung oleh pelatih yang telah memiliki sertifikat provider. Hal ini sejalan dengan penelitian (Sutono dkk, 2015) yang menyatakan pelatihan dengan umpan balik pelatih dapat langsung memberikan koreksi dan perintah jika dalam melakukan prosedur kurang tepat. Selain itu, peserta dapat secara langsung bertanya, sehingga peserta akan lebih paham dalam proses pelatihan.

Faktor lain yang dapat meningkatkan pengetahuan peserta pelatihan yaitu dengan pemberian modul. Hal ini didukung oleh penelitian Somantri (2015) yang menyatakan pemberian modul dapat menambah paparan responden terkait bantuan hidup dasar. Modul dapat bermanfaat bagi peserta untuk belajar secara mandiri dan responden dapat mempelajarinya diluar waktu pelatihan.

Selain edukasi melalui pelatihan melalui konsep simulasi terdapat beberapa metode lain dalam meningkatkan pengetahuan, diantaranya yaitu melalui video. Pelatihan menggunakan video memiliki kelebihan tersendiri yaitu peserta dapat belajar secara mandiri menggunakan video dimana saja dan kapan saja. Berdasarkan penelitian yang dilakukan oleh Metrikayanto, dkk (2019) edukasi melalui video merupakan inovasi dalam pelatihan bantuan hidup dasar. Penelitian ini menjelaskan bahwa pelatihan melalui video merupakan metode yang efektif dalam mengajarkan masyarakat awam terkait bantuan hidup dasar. Hasil pada penelitian ini menunjukkan tidak terdapat perbedaan peningkatan pengetahuan antara metode simulasi dengan metode pelatihan $\mathrm{p}=0,468$ ( $\mathrm{p}>0,05)$. Kedua pelatihan dapat meningkatkan pengetahuan responden walaupun menggunakan metode yang berbeda. Namun pelatihan menggunakan video memiliki mean difference lebih besar dibandingkan menggunakan metode simulasi.

Hasil penelitian ini juga sejalan dengan penelitian yang dilakukan oleh Sansare dan Jacob (2018) yaitu pengaruh pelatihan bantuan hidup dasar terhadap pengetahuan dan keterampilan pada Karyawan dengan nilai $\mathrm{p}=0,000<0,005$, disimpulkan terdapat pengaruh pelatihan terhadap keterampilan. Penelitian lain yang dilakukan oleh Rachmat (2019) terkait pengaruh pelatihan bantuan hidup dasar terhadap pengetahuan dan keterampilan menunjukkan hasil $p=0,0001<0,05$ maka disimpulkan terdapat pengaruh bantuan hidup dasar dengan keterampilan.

Pelatihan merupakan konsep belajar yang berfokus kepada keterampilan. Pelatihan membentuk dasar dari pelaksanaan keterampilan seseorang. Pelatihan seharusnya menjadi hal yang berkesinambungan dengan tujuan mengingat serta memperbarui lagi pengetahuan dan keterampilan yang dimiliki. Menurut Keenan (2009) pelatihan kembali harus dilakukan 6-12 bulan untuk mempertahankan keterampilan bantuan hidup dasar.

Berdasarkan penelitian yang dilakukan Widyarani (2018) dengan judul analisis pengaruh pelatihan resusitasi jantung paru dewasa terhadap retensi pengetahuan dan keterampilan rjp pada mahasiswa keperawatan di yogyakarta didapatkan hasil keterampilan siswa menurun setelah 1 bulan penelitian. Hasil penelitian ini menunjukkan nilai rata-rata keterampilan sebelum dilakukan 
pelatihan yaitu 35,55 dan setelah selesai pelatihan nilai rata-rata keterampilan yaitu 91,80. Setelah satu bulan kemudian dilakukan kembali penilaian keterampilan pada responden dan didapatkan nilai rata-rata keterampilan yaitu 70,61. Penurunan nilai rata-rata keterampilan ini didasari karena kurangnya paparan terkait bantuan hidup dasar kepada responden. Kualitas keterampilan yang tinggi membutuhkan pelatihan yang berkesinambungan.

Pelatihan yang dilakukan sebanyak tiga kali merupakan faktor pendukung terjadinya peningkatan keterampilan pada responden. Berdasarkan penelitian Lee dkk (2016) berjudul pengaruh durasi pelatihan bantuan hidup dasar terhadap keterampilan resusitasi jantung paru yang menyatakan bahwa lama waktu pelatihan akan memiliki dampak yang cukup signifikan terhadap keterampilan seseorang. Penelitian ini membagi responden menjadi 4 kelompok berdasarkan waktu pelatihan. Penelitian ini menunjukkan terdapat perbedaan keterampilan antara pelatihan berdurasi 40 menit dengan pelatihan berdurasi 180 menit $(p<0,001)$ Hasil penelitian tersebut menunjukkan bahwa pelatihan dengan durasi singkat dapat meningkatkan keterampilan terkait BHD. Namun, pelatihan dalam jangka waktu yang lama akan menghasilkan kualitas yang tinggi terkait RJP. Penelitian ini juga menyebutkan pelatihan BHD dapat meningkatkan kepercayaan diri dan kemauan untuk menolong orang yang membutuhkan pertolongan selama henti jantung, terlepas dari lama penelitian.

Faktor lain yang membuat keterampilan responden meningkat secara signifikan yaitu tidak terlepas dari penggunaan phantom sebagai alat peraga. Berdasarkan penelitian yang dilakukan Andita (2016) yaitu pengaruh pendidikan kesehatan sadari dengan media slide dan benda tiruan terhadap perubahan pengetahuan didapatkan hasil penggunaan alat tiruan (phantom) dapat meningkatkan pengetahuan dan keterampilan seseorang. Penggunaan alat peraga dapat membuat responden seolah-olah menolong korban sesungguhnya. Selain itu, dengan menggunakan alat peraga maka akan semakin banyak panca indera yang digunakan sehingga informasi dan keterampilan yang didapat akan lebih banyak. Namun, peran pelatih masih sangat dominan karena keberadaan phantom hanya sebagai sarana untuk demonstrasi skill.

Keterampilan dapat dibentuk melalui pelatihan melalui berbagai media. Semakin banyak media yang digunakan maka keahlian dan retensi pengetahuan akan lebih berkualitas. Pada penelitian yang dilakukan oleh (Sutono dkk, 2015) yang berjudul perbedaan nilai kompresi dada dan ventilasi pada pelatihan resusitasi jantung paru mahasiswa S1 keperawatan dengan umpan balik instruktur, audiovisual dan kombinasi didapatkan nilai rata-rata kedalaman kompresi dada metode instruktur yaitu 47,17 metode audio visual sebesar 48,15 dan metode kombinasi sebesar 49,17. Hasil ini menunjukkan dari perubahan rerata nilai kompresi dada dari pretest ke post-test, maka metode kombinasi menunjukkan perubahan yang lebih baik dari kedua metode yang lain. Ini menunjukkan bahwa pelatihan dengan instruktur dan didukung menggunakan audio visual lebih disarankan dalam meningkatkan skill responden sehingga mencapai hasil yang lebih optimal.

Faktor kecemasan, grogi saat demonstrasi, kurang percaya diri, malu juga mempengaruhi hasil keterampilan. Dalam hal ini faktor campur tangan pelatih sangat diperlukan untuk mengatasinya. Metode kombinasi dengan panduan yang lebih lengkap dapat meningkatkan kepercayaan diri saat demonstrasi, hal inilah yang ikut berpengaruh terhadap hasil dimana metode kombinasi meskipun secara statistik tidak berbeda, tetapi dari rerata nilai, hasilnya sedikit lebih baik dari metode pelatihan dengan instruktur dan audio visual (Sutono dkk., 2015).

\section{SIMPULAN}

Terdapat pengaruh pelatihan Bantuan Hidup Dasar (BHD) terhadap pengetahuan pada himpunan mahasiswa kesehatan masyarakat di UPN "Veteran" Jakarta. Terdapat pengaruh pelatihan Bantuan Hidup Dasar (BHD) terhadap keterampilan pada himpunan mahasiswa kesehatan masyarakat di UPN "Veteran" Jakarta. Hal ini menunjukkan pelatihan dapat meningkatkan pengetahuan dan keterampilan. 


\section{SARAN}

Berdasarkan hasil penelitian yang dilakukan terdapat beberapa hal yang dapat direkomendasikan yaitu penelitian ini dapat menjadi dasar untuk pentingnya memberikan pelatihan bantuan hidup dasar kepada mahasiswa khususnya mahasiswa kesehatan diluar kedokteran dan keperawatan untuk meningkatkan pengetahuan dan keterampilan mahasiswa kesehatan terhadap kemampuan bantuan hidup dasar. Selanjutnya diharapkan dapat dilakukan penelitian eksperimen dengan menggunakan sampel yang lebih banyak, serta mengguanakan kelompok kontrol untuk melihat pengaruh pelatihan terhadap pengetahuan dan keterampilan dan juga untuk meneliti variabel perancu yang memiliki hubungan dengan pengetahuan dan keterampilan. Lebih jauh lagi, institusi pendidikan hendaknya memiliki program pembelajaran terkait pelatihan Bantuan Hidup Dasar (BHD) yang mulai diajarkan sejak pendidikan dasar hingga tingkat pendidikan tinggi.

\section{DAFTAR PUSTAKA}

Al-Mohaissen, MA.(2017).Knowledge and attitudes towards basic life support among health students at a Saudi women's university.Sultan Qaboos University Medical Journal, diakses pada 8 Maret 2019, https://doi.org/10.18295/squmj.2016.17.01.011

American Heart Association (AHA). (2017). About cardiac arrest, diakses pada 15 Maret 2019, https://www.heart.org/en/health-topics/cardiac-arrest/aboutcardiac-arrest

American Heart Association (AHA). (2017). Cardiac arrest statistics, diakses pada 15 Maret 2019, https://cpr.heart.org/AHAECC/CPRAndECC/ResuscitationScience/UCM_477263_AHACardiac-Arrest-Statistics.jsp $\% 5 \mathrm{BR}=301, \mathrm{~L}, \mathrm{NC} \% 5 \mathrm{D}$

American Heart Association (AHA).(2018).How CPR is changing (and saving) lives. Diakses pada 18 Maret 2019, https://cpr.heart.org/AHAECC/CPRAndECC/AboutCPRECC/CPRFactsAndStats/UCM_4 75748_CPR-Facts-and-Stats.jsp

Andita, U.(2016).Pengaruh pendidikan kesehatan sadari dengan media slide dan benda tiruan terhadap perubahan pengetahuan wanita usia subur. Jurnal Promkes.Vol. 4, no.2, diakses pada 9 Juni 2019

https://www.researchgate.net/publication/331838132_pengaruh_pendidikan_kesehatan_sa dari_dengan_media_slide_dan_benda_tiruan_terhadap_perubahan_pengetahuan_wus/link/ 5c8fa83f92851c1df949ce1d/download

D Prasetyo, R.(2019).Pengaruh latihan basic life support terhadap pengetahuan dan keterampilan tim Muhammadiyah Disaster Management (MDMC) Banyumas.Prosiding seminar nasional 2018. Diakses pada 20 Juni 2019.

https://doi.org/10.32528/psn.v0i0.1732

Ganthikumar, K.(2017).Indikasi dan keterampilan Resusitasi Jantung Paru (RJP).Intisari Sains Medis. diakses pada 2 Maret 2019,

https://doi.org/10.15562/ism.v6i1.20

Ghauri, S, Khan, H, Bangash, M, Mustafa, K, \& Khan, A.(2019).Impact of Basic Life Support Training on the knowledge of Basic Life Support in Undergraduate Medical Students. South Asian Journal of Emergency Medicine. Vol.1 diakses pada 20 Juni, https://doi.org/10.5455/sajem/184-1532789417

Graham, R, McCoy, MA, \& Schultz, AM.(2015).Strategies to Improve Cardiac Arrest Survival: A Time to Act.National Academies Press, diakses pada 20 Februari 2019,

https://books.google.co.id/books?id=XOa7CgAAQBAJ\&printsec=frontcover\&dq=Strategies+to $+\mathrm{I}$ mprove+Cardiac+Arrest+Survival:+A+Time+to+Act\&hl=id\&sa=X\&ved=0ahUKEwig9fOqn9vj AhUEOY8KHeLRChsQ6AEIKTAA\#v=onepage\&q=Strategies $\% 20$ to $\% 20 I m p r o v e \% 20$ Cardiac $\%$ 20Arrest $\% 20$ Survival $\% 3 \mathrm{~A} \% 20 \mathrm{~A} \% 20$ Time $\% 20$ to $\% 20$ Act\&f=false 
Hasselqvist-Ax, I, Ringh, M, Hollenberg, J, Karlsson, T, Axelsson, C, Nordberg, P, Herlitz, J.(2015). 'Early Cardiopulmonary Resuscitation in Out-of-Hospital Cardiac Arrest', New England Journal of Medicine, diakses pada 24 Maret 2019, https://doi.org/10.1056/nejmoa1405796

Hawkes, C, Booth, S, Ji, C, Brace-McDonnell, SJ, Whittington, A, Mapstone, J, Perkins, GD. (2017). 'Epidemiology and outcomes from out-of-hospital cardiac arrests in England'. Resuscitation, diakses pada 3 Maret 2019, https://doi.org/10.1016/j.resuscitation.2016.10.030

Keenan, M, Lamacraft, G, \& Joubert, G.(2009).A Survey of Nurses' Basic Life Support Knowledge and Training at a Tertiary Hospital'.African Journal of Health Professions Education, diakses pada 18 Juni 2019, https://doi.org/10.7196/ajhpe.15

Larasati, S.(2018).Manajemen Sumber Daya Manusia. Deepublish, diakses pada 18 Maret 2019, https://books.google.co.id/books?id=XRRkDwAAQBAI\&pg=PA23\&hl=id\&source=gbs_toc $\mathrm{r} \& \mathrm{cad}=4 \# \mathrm{v}=$ onepage \& $\mathrm{q} \& \mathrm{f}=$ false

Lee, JH, Cho, Y, Kang, KH, Cho, GC, Song, KJ, \& Lee, CH.(2016).'The Effect of the Duration of Basic Life Support Training on the Learners Cardiopulmonary and Automated External Defibrillator Skills', BioMed Research International, diakses pada 22 Juni 2019, https://doi.org/10.1155/2016/2420568

Metrikayanto, WD, Saifurrohman, M, \& Suharsono, T. (2019).Perbedaan Metode Simulasi dan Self Directed Video Terhadap Pengetahuan,Sikap dan Ketrampilan Resusitasi Jantung Paru (RJP) Menggunakan I-Carrer Cardiac Resuscitation Manekin Pada Siswa SMA Anggota Palang Merah Remaja (PMR)', Care : Jurnal Ilmiah Ilmu Kesehatan, diakses pada 18 Maret 2019, https://doi.org/10.33366/cr.v6i1.792

Ong, MEH, Shin, SD, De Souza, NN, Tanaka, H, Nishiuchi, T, Song, KJ, Gan, HN.(2015).'Outcomes for out-of-hospital cardiac arrests across 7 countries in Asia: The Pan Asian Resuscitation Outcomes Study (PAROS)', Resuscitation, diakses pada 10 Maret 2019, https://doi.org/10.1016/j.resuscitation.2015.07.026

Owojuyigbe, A, Adenekan, A, Faponle, A, \& Olateju, S.(2015).'Impact of basic life support training on the knowledge of basic life support in a group of Nigerian Dental Students', Nigerian Postgraduate Medical Journal, diakses pada 15 Maret 2019, https://doi.org/10.4103/1117$\underline{1936.170740}$

Raffee, LA, Samrah, SM, Al Yousef, HN, Abeeleh, MA, \& Alawneh,KZ. (2017). 'Incidence, Characteristics, and Survival Trend of Cardiopulmonary Resuscitation Following In-hospital Compared to Out-of-hospital Cardiac Arrest in Northern Jordan', Indian Journal of Critical Care Medicine: Peer-Reviewed, Official Publication of Indian Society of Critical Care Medicine, diakses pada 28 Maret 2019, https://doi.org/10.4103/ijccm.IJCCM_15_17

Sansare, KR, \& Jacob, S. (2018). 'Effect of basic life support training programme on knowledge and practice among administrative employees of health institutes, Navi Mumbai', International Journal of Nursing Education and Research, diakses pada 3 Maret 2019, https://doi.org/10.5958/2454-2660.2018.00039.x

Somantri, DW.(2015).Pelaksanaan pembelajaran menggunakan media modul di Sekolah Dasar Negeri 8 Banjar Universitas Negeri Yogyakarta diakses pada 25 Juni 2019,

http://journal.student.uny.ac.id/ojs/ojs/index.php/fiptp/article/download/700/679

Suranadi, I.(2017).Tingkat Pengetahuan Tentang Bantuan Hidup Dasar (BHD) Mahasiswa Fakultas Kedokteran Universitas Udayana, diakses pada 3 Maret 2019, https://simdos.unud.ac.id/uploads/file_penelitian_1_dir/973304fec3de838114b0870bf7dbfb4 $\underline{0 . p d f}$

Sutono, S, Ratnawati, R, \& Suharsono, T.(2015). 'Perbedaan nilai kompresi dada dan ventilasi pada pelatihan resusitasi jantung paru mahasiswa S1 Keperawatan dengan umpan balik instruktur, audiovisual dan kombinasi di Yogyakarta', Jurnal Ilmu Keperawatan, Vol.3, no.2, diakses pada 
18 Juni 2019, https://elearning.uui.ac.id/publik/download/1547826_jurnal_rip_4.pdf

Widyarani, L.(2018).'Analisis pengaruh pelatihan resusitasi jantung paru rjp dewasa terhadap retensi pengetahuan dan ketrampilan rjp pada mahasiswa keperawatan di Yogyakarta', Jurnal Keperawatan Soedirman, diakses pada 22 Juni 2019, https://doi.org/10.20884/1.jks.2017.12.3.718

Yayasan Ambulans Gawat Darurat 118.(2018).Basic Trauma Life Support E Basic Cardiac Life Support, Rineka Cipta, Jakarta.

Yunus, M, Mishra, A, Karim, H, Raphael, V, Ahmed, G, \& Myrthong, C.(2015).'Knowledge, attitude and practice of basic life support among junior doctors and students in a tertiary care medical institute', International Journal of Research in Medical Sciences, diakses pada 25 Maret 2019, https://doi.org/10.18203/2320-6012.ijrms20151416 